\section{Empyema of gallbladder in an infant}

Although acute cholecystitis has been described in the past in published reports as a complication of scarlet fever and typhoid (Swing and Bullowa, 1938; Reid and Montgomery, 1920), and perforation of the gallbladder has been noted in infants (Prévot and Babut, 1971), empyema of the gallbladder remains rare.

\section{Case report}

A female, birthweight $3.35 \mathrm{~kg}$ after a normal pregnancy, was bottle fed and was well until the 10th day of life when she developed a paronychia of the left thumb and an infected spot on her back for which no treatment was given. At age one month the baby was admitted to hospital with a 3-day history of fever up to $39^{\circ} \mathrm{C}$ and feeding poorly. On examination the liver was palpable $1 \mathrm{~cm}$ below the costal margin. The white cell count was $17000 / \mathrm{mm}^{3}$, of which $46 \%$ were neutrophils. Blood and CSF cultures were sterile. Treatment with ampicillin and flucloxacillin was given by injection. Her temperature settled and feeding improved. On the third day after admission a tender hard mass was noted apparently arising from the medial third of the liver. Further investigations showed that $\mathrm{Hb}$ had dropped from $10 \cdot 3 \mathrm{~g} / \mathrm{dl}$ to $7 \cdot 6 \mathrm{~g}$. Plasma bilirubin was $0.3 \mathrm{mg} / 100 \mathrm{ml}$; plasma glutamic oxaloacetic transaminase $14 \mathrm{IU} / 1$; plasma glutamic pyruvic transaminase $10 \mathrm{IU} / 1$; alkaline phosphatase $15 \mathrm{KA}$ units/ $100 \mathrm{ml}$.

The control film (Fig. 1) of the otherwise normal intravenous pyelogram revealed a mass continuous with

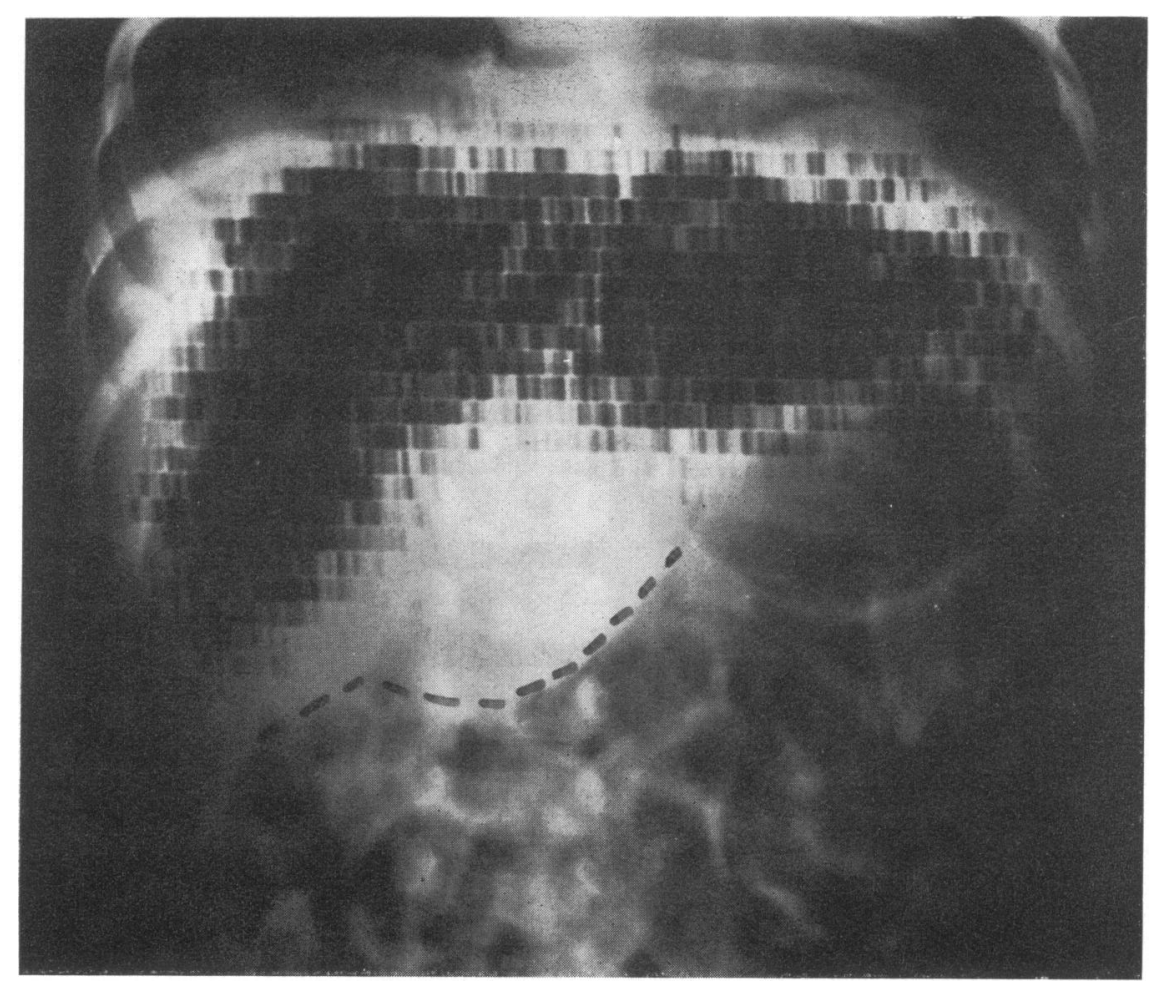

FIG. 1.-Plain film of upper abdomen with mass and liver edge marked and liver scan superimposed. 


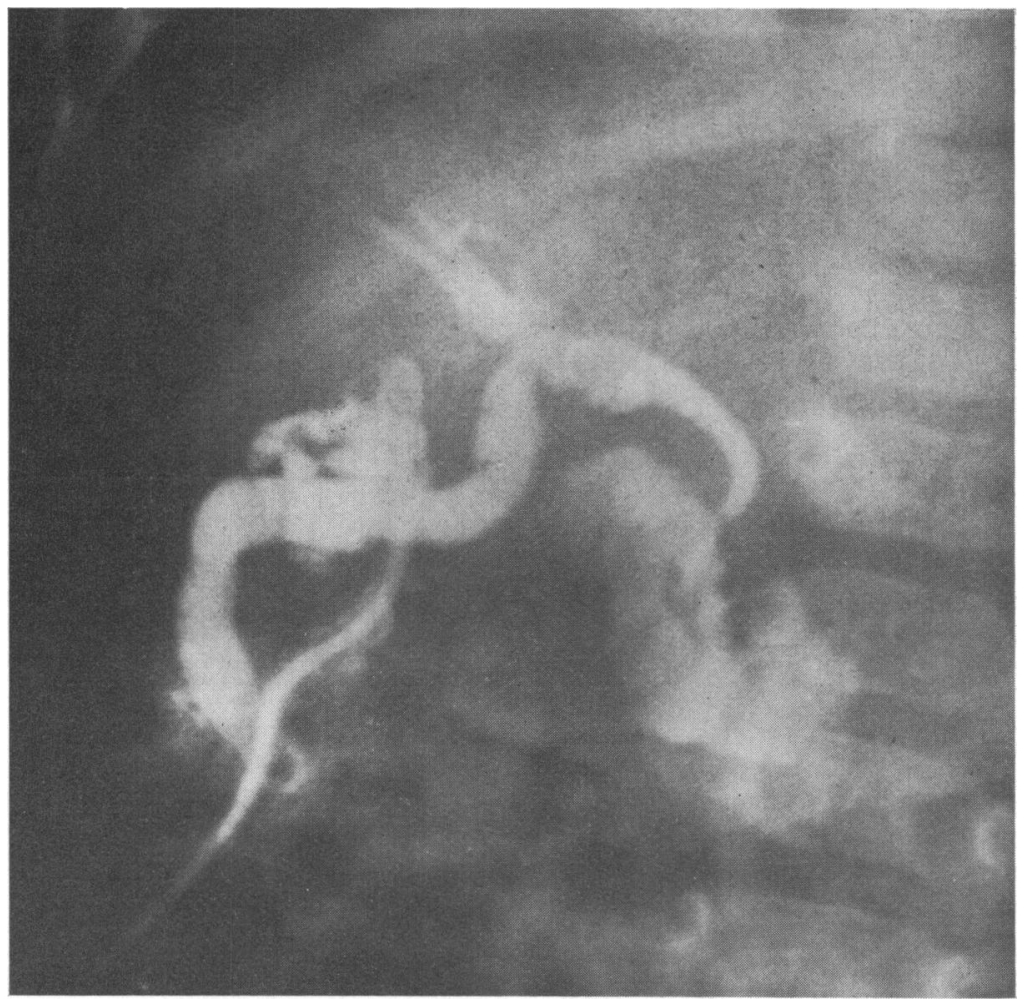

FIG. 2.-Postoperative cholangiogram showing patent biliary system.

the presumed liver edge, but the superimposed isotopic liver scan ${ }^{99 \mathrm{~m}} \mathrm{Tc}$-sulphur-colloid) showed a defect in uptake at this site. Laparotomy (Mr. G. L. Bunton) revealed a grossly swollen and inflamed gallbladder (with adhesions to the omentum, transverse colon, and duodenum) which when opened revealed thick pus. A catheter was left in the gallbladder to drain transcutaneously. A rapid and uneventful recovery was made under antibiotic cover.

Two weeks after operation, water soluble contrast was introduced via the draining catheter and filled, via the drainage tract, a patent gallbladder and biliary tract, with free passage into the duodenum (Fig. 2).

\section{Discussion}

No evidence of calculus obstruction or of haemolysis was present in this case and it seems possible that haematogenous spread of infection from the skin led to colonization of the gallbladder. The cause of most cases of spontaneous perforation of the bile ducts is also often obscure.

With many manufacturers recommending avoidance of intravenous cholangiography in the young and the often disappointing results in oral cholecystography, a radioactive liver scan which delineates normal hepatic parenchyma can be a useful adjunct to excretory urography and barium studies in the evaluation of upper abdominal masses. Transcutaneous postoperative cholangiography was necessary to ensure that there was no residual obstruction to the biliary tree, which will be investigated later by oral cholecystography.

\section{Summary}

Empyema of the gallbladder was diagnosed in a 1-month-old infant, aided by isotopic liver scan.

We are grateful to our colleagues Mr. G. L. Bunton and Professor L. B. Strang.

\section{REFERENCES}

Prévot, J., and Babut, J. M. (1971). Spontaneous perforations of the biliary tract in infancy. Progress in Pediatric Surgery, p 187. Ed. by P. P. Rickham, W. C. Hecker, and J. Prévot. University Park Press, Baltimore.

Reid, M. R., and Montgomery, J. C. (1920). Acute cholecystitis in children as a complication of typhoid fever. Bulletin fohns Hopkins Hospital, 31, 7.

Swing, A. T., and Bullowa, J. G. M. (1938). Acute cholecystitis complicating scarlet fever. American fournal of Diseases of Children, 55, 521 . 
P. Noble Jamieson and D. G. Shaw ${ }^{\star}$

Departments of Paediatrics and Radiology, University College Hospital, Gower Street, London WC1E $6 A U$.

^Correspondence to Dr. D. G. Shaw. normal. 4 were obtained by hysterotomy; of these, 3 had chromosome abnormalities (Down's syndrome), while the fourth was a male fetus borne by a female carrier of the gene for haemophilia. CSF from these fetuses was collected within 2-5 hours of the hysterotomy. Ages of the fetuses ranged between $16 \frac{1}{2}$ and $25 \frac{1}{2}$ weeks (Table I).

\section{TABLE I}

Age, cause of abortion, and chromosome complement of the 6 fetuses studied

\begin{tabular}{|c|c|c|c|}
\hline Fetus & Age (w) & $\begin{array}{l}\text { Causes of } \\
\text { abortion }\end{array}$ & $\begin{array}{l}\text { Chromosome } \\
\text { complements }\end{array}$ \\
\hline $\begin{array}{l}1 \\
2 \\
3 \\
4 \\
5 \\
6\end{array}$ & $\begin{array}{l}16 \frac{1}{2} \\
19 \frac{1}{2} \\
18 \\
25 \\
25 \frac{1}{2} \\
25 \frac{1}{2}\end{array}$ & $\begin{array}{l}\text { Spontaneous } \\
\text { Spontaneous } \\
\text { Induced } \\
\text { Induced } \\
\text { Induced } \\
\text { Induced }\end{array}$ & $\begin{array}{l}\text { Not tested } \\
\text { Not tested } \\
47, \mathrm{XY},+\mathrm{G} \\
46, \mathrm{XY} \\
46, \mathrm{XY}-\mathrm{G}+\mathrm{t}(\mathrm{DqGq}) \\
\text { 47,XY },+\mathrm{G}\end{array}$ \\
\hline
\end{tabular}

Albumin level was measured by the single radial diffusion technique and AFP by the one dimensional antigen-antibody electrophoresis (rocket technique), as previously described (Seller et al., 1973). IgG levels were estimated using commercially available immunoplates (Behringwerke, AG, Marburg, Germany).

\section{Results and conclusions}

AFP levels in fetal CSF were found to decline from $1220 \mu \mathrm{g} / \mathrm{ml}$ in the $16 \frac{1}{2}$-week-old fetus to 52 and $60 \mu \mathrm{g} / \mathrm{ml}$ in the older fetuses tested (Table II). Reduction of the concentration of AFP in CSF, in relation to the ages of the fetuses, was more rapid than that of the levels of AFP in fetal sera. The ratios between the amounts of albumin and AFP in CSF increased with age, passing from 1.8 in a fetus 18 weeks old to 20 in a fetus $25 \frac{1}{2}$ weeks old.

IgG in adult CSF ranges from $20-40 \mu \mathrm{g} / \mathrm{ml}$ (Davson, 1967; Laterre, 1973). It was therefore of great interest to find higher levels of $\mathrm{IgG}$ in the CSF of the fetuses. Since most of the IgG present

TABLE II

Levels of AFP, albumin, and $\operatorname{IgG}$ in CSF from 6 fetuses

\begin{tabular}{|c|c|c|c|c|c|c|c|}
\hline \multirow{2}{*}{ Fetus } & \multicolumn{3}{|c|}{ Levels of AFP $(\mu \mathrm{g} / \mathrm{ml})$} & \multicolumn{4}{|c|}{ CSF levels $(\mu \mathrm{g} / \mathrm{ml})$ of } \\
\hline & (1) CSF & (2) Serum & $1 / 2$ & (3) Alb & $3 / 1$ & (4) IgG & $3 / 4$ \\
\hline $\begin{array}{l}1 \\
2 \\
3 \\
4 \\
5 \\
6\end{array}$ & $\begin{array}{r}1220 \\
1040 \\
420 \\
71 \\
52 \\
60\end{array}$ & $\begin{array}{rr} & N \\
2720 & N \\
1380 & \\
840 & \\
690 & \end{array}$ & $\begin{array}{c}6 \cdot 47 \\
11 \cdot 4 \\
16 \cdot 4 \\
11 \cdot 5\end{array}$ & $\begin{array}{r}760 \\
840 \\
680 \\
1200\end{array}$ & $\begin{array}{r}1 \cdot 8 \\
11 \cdot 8 \\
13 \cdot 1 \\
20 \cdot 0\end{array}$ & $\begin{array}{r}\text { ted } \\
\text { ted } \\
72 \\
117 \\
60 \\
109\end{array}$ & $\begin{array}{r}10 \cdot 5 \\
7 \cdot 12 \\
11 \cdot 3 \\
11 \cdot 0\end{array}$ \\
\hline
\end{tabular}

